\title{
Using Statistical Downscaling of GCM Simulations to Assess Climate Change Impacts on Drought Conditions in the Northwest of Morocco
}

\author{
Mohamed Elkharrim ${ }^{1} \&$ Lahcen Bahi ${ }^{2}$ \\ ${ }^{1}$ Direction de la Météorologie Nationale, Casablanca, Morocco \\ ${ }^{2}$ Mohammed V University, Ecole Mohammadia d'Ingénieurs, Rabat, Morocco \\ Correspondence: Mohamed Elkharrim, Direction de la Météorologie Nationale, B.P:8106, Casa-Oasis \\ Casablanca, Morocco. Tel: 212-0522-654-900. E-mail: kharrim@gmail.com
}

Received: September 15, 2014

Accepted: October 16, $2014 \quad$ Online Published: November 27, 2014

doi:10.5539/mas.v9n2p1

URL: http://dx.doi.org/10.5539/mas.v9n2p1

\begin{abstract}
The present study focus on a statistical approach for improving climate prediction for the region of the Bouregreg basin in the northwest of Morocco. The aim was to examine the past drought conditions and to find their trend under climate change conditions. Past and future drought conditions were assessed using Standard Precipitation Index (SPI) by considering the emission scenarios A2 and B2 for three periods 2014-2040, 2041-2070 and 2071-2099. A statistical downscaling method was applied to the HadCM3 outputs for the station of Rabat to simulate the projected changes in precipitation and temperature. Results shows that annual precipitations under A2 scenario increased by $4.72 \%, 4.75 \%$ and $4.50 \%$ for the periods $2014-2040,2041-2070$ and 2071-2099 respectively, for the B2 scenario increased by $4.19 \%, 5.0 \%$ and $4.58 \%$ for the $2014-2040$, 2041-2070 and 2071-2099 periods respectively. The annual mean maximum temperature under A2 scenario increased by $2.24 \%, 7.43 \%$ and $16.31 \%$ for $2014-2040,2041-2070$ and $2071-2099$ periods respectively, and for the B2 scenario increased by $3.07 \%, 6.97 \%$ and $10.0 \%$ for $2014-2040,2041-2070$ and $2071-2099$ periods respectively. The results showed also an overall decrease of annual and seasonal drought severity over the years. The annual and seasonal drought severity and duration for the periods 2025-2045 and 2055-2070 will increase under A2 and decrease under B2 scenario.
\end{abstract}

Keywords: drought, statistical downscaling, SPI index, climate change

\section{Introduction}

Drought is a natural hazard that can have serious consequences for a range of human activities. Its impacts are more felt economically and socially: agricultural production and water resource availability for industry and households being the most affected sectors, particularly in areas of the world that do not have the infrastructure to effectively mitigate its affects. Drought is often seen as a "creeping" phenomenon with slow onset and cessation. As a result, an effective drought monitoring system is the most important tool for developing and implementing efficient mitigation strategies. However, not only can the onset of drought conditions be rapid, an indication of how long drought conditions may continue will enable improved planning and resource allocation. For this reason, a capability to accurately forecast the onset, persistence and cessation of drought conditions will enable more effective drought mitigation strategies to be developed.

Drought can be defined as a period of time with water availability less than some specified amount at a particular location. It is primarily driven by a shortage of precipitation, the effects of which can be enhanced or reduced at any stage of the water cycle. Therefore, as a means towards developing a drought forecasting system, this study concentrates on forecasting the temperature and precipitation contribution towards drought conditions.

The rainfall distribution in Morocco is very scarce and characterized by high annual variability. Several economic sectors depend on the average annual rainfall like agriculture and tourism. Therefore, economy become very sensitive to climate changes and thus water management projects are highly requested. The study of rainfall distribution and the future trends is an essential task to better planning and managing water resources.

Some studies associate rainfall variability in the northern of Morocco to the North Atlantic Oscillation (Knippertz et al.2003a) which have a major impact on winter climate. High Moroccan precipitation tends to coincide with large negative anomalies of the NAO while drought in Morocco is related to a positive state of 
NAO. The need of regional understanding of precipitation variability in northern Morocco seems to be very important to better forecast drought occurrence and develop efficient mitigations methods.

General Circulation Models (GCMs) have recently been deployed for weather forecasting and climate change projections, and can reasonably represent the large-scale aspects of climate, but they do not provide enough prediction information for the local and regional climate because of their coarse resolution of several hundreds of kilometers (Juneng et al. 2010).

Statistical downscaling is a two step process consisting of the development of statistical relationship between local climate variables like "precipitation" and large scale predictors like "pressure field" and the application of such relationships to the output of GCMs to simulate local climate characteristics in the future. Statistical downscaling is used in climate impact assessment at regional and local scales and when suitable observed data are available to derive the statistical relationships.

\section{Datasets and Methods}

\subsection{Study Area}

The target area of this study is the region of Bouregreg basin in the northwest region of Morocco (figure 1) $\left(32^{\circ} 06^{\prime}-35^{\circ} 56^{\prime} \mathrm{N}, 3^{\circ} 46^{\prime}-8^{\circ} 01^{\prime} \mathrm{W}\right)$ which covers a total area of $62960 \mathrm{~km}^{2}$. The Bouregreg basin covers an area of $9771 \mathrm{~km}^{2}$. It's altitude range from sea level to $1724 \mathrm{~m}$. The climate is semi arid influenced by altitude, latitudinal extension and the opening of the region on the Atlantic costs. Precipitations recorded in area with high altitude (Northeast and Southeast) are higher than in plain. Latitudinal extension leads to a climatic pattern temperate in the North and semi arid in south. Region exposed to Atlantic Ocean are more wetted with moderate temperatures. The mean annual temperature is $18{ }^{\circ} \mathrm{C}$ and the total average annual precipitation is $440 \mathrm{~mm}$. the precipitation decrease slightly with the latitude and range from $480 \mathrm{~mm} / \mathrm{y}$ in Rabat to less than $370 \mathrm{~mm} / \mathrm{y}$ in the southwest of the basin. However its show a strong increases with altitude and reach $760 \mathrm{~mm} / \mathrm{y}$ at the highest location. The mean annual evapotranspiration is $1600 \mathrm{~mm}$ in the coastal region of Rabat and $800 \mathrm{~mm}$ in the high region of Bouregreg. We focus in this study to the station of Rabat which has a considerable historical quality data.

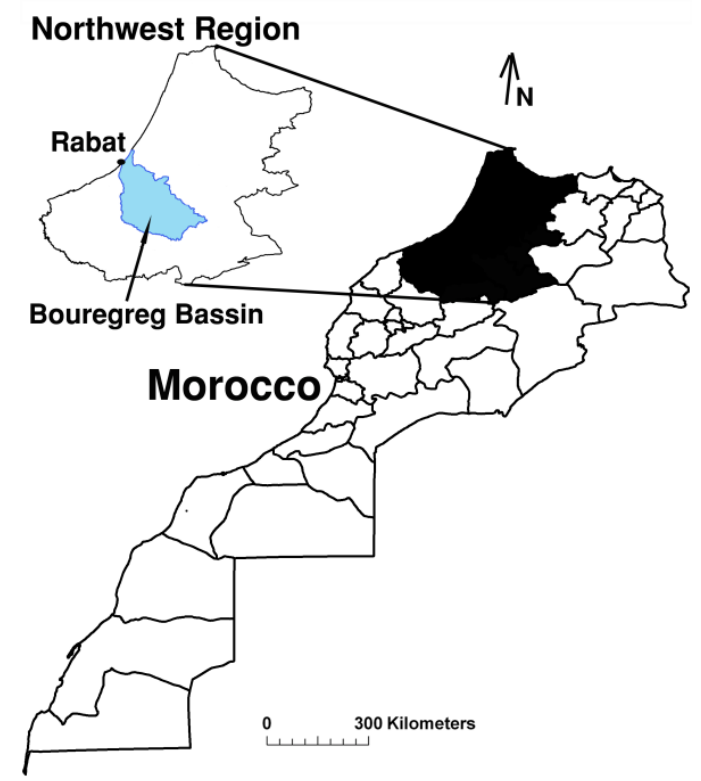

Figure 1. Localisation of the northwest region of Morocco

In this study we have used the HadCM3 model simulations, where the outputs were downscaled by the Automated Statistical Downscalling (ASD) model (Hessami et al. 2008) inspired by the existing Statistical Downscaling Model (SDSM, developed by Wilby et al., 2002). Figure 2 shows the general scheme of the ASD algorithm for generating climate scenario information. 
Table 1. Predictor used in the downscaling process derived from CCCSN

\begin{tabular}{rlrl}
\hline No. & Predictor & No. & Predictor \\
\hline 1 & Mean sea level pressure & 14 & $500 \mathrm{hPa}$ divergence \\
2 & $1000 \mathrm{hPa}$ airflow strength & 15 & $850 \mathrm{hPa}$ air flow strength \\
3 & $1000 \mathrm{hPa}$ zonal velocity & 16 & $850 \mathrm{hPa}$ zonal velocity \\
4 & $1000 \mathrm{hPa}$ meridional velocity & 17 & $850 \mathrm{hPa}$ meridional velocity \\
5 & $1000 \mathrm{hPa}$ vorticity & 18 & $850 \mathrm{hPa}$ vorticity \\
6 & $1000 \mathrm{hPa}$ wind direction & 19 & $850 \mathrm{hPa}$ geopotential height \\
7 & $1000 \mathrm{hPa}$ divergence & 20 & $850 \mathrm{hPa}$ wind direction \\
8 & $500 \mathrm{hPa}$ airflow strength & 21 & $850 \mathrm{hPa}$ divergence \\
9 & $500 \mathrm{hPa}$ zonal velocity & 22 & Relative humidity at $500 \mathrm{hPa}$ \\
10 & $500 \mathrm{hPa}$ meridional velocity & 23 & Relative humidity at $850 \mathrm{hPa}$ \\
11 & $500 \mathrm{hPa}$ vorticity & 24 & $1000 \mathrm{hPa}$ relative humidity* \\
12 & $500 \mathrm{hPa}$ geopotential height & 25 & Specific humidity at $2 \mathrm{~m}$ \\
13 & $500 \mathrm{hPa}$ wind direction & 26 & Mean temperature at $2 \mathrm{~m}$ \\
\hline
\end{tabular}

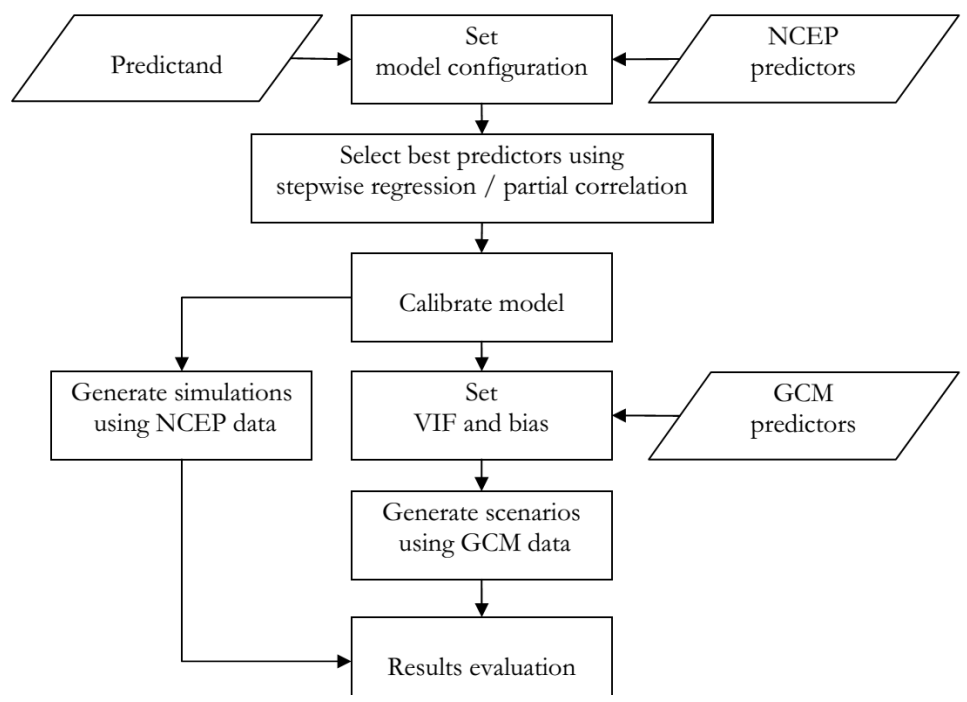

Figure 2. Algorithm of the ASD model

\subsection{Station Data}

Observation data used in this study derive from the GHCN (Global Historical Climatology Network-Monthly) version 3 which integrate methods for removing inhomogeneities from the data record associated with non-climatic influences such as changes in instrumentation, station environment, and observing practices that occur over time. Version 3 replace version 2 with efforts focused on continued improvements in dataset development methods including new quality control processes and advanced techniques for removing data inhomogeneities (J. H. Lawrimore et al. 2011).

Data used for predictors derived from the National Centers for Atmospheric Prediction (NCEP) and the National Center for Atmospheric Research (NCAR) that have accomplished different re-analysis projects which aim on the generation of global data sets for a long time period for different atmospheric parameters. The re-analysis is created with a model similar to the one used for weather forecasts. This model is initialized with measured data from different sources, including observations from weather stations, ship, aircraft, radiosonde, and satellite. Using one model for the whole re-analysis period generates homogeneous data that can be used for long term studies (Kalnay et al. 1996).

\subsection{General Circulation Model (GCM) Output}

For future projection we used data from the HadCM3 model which is a coupled climate model that has been used extensively for climate prediction, detection and attribution, and other climate sensitivity studies. HadCM3 was 
one of the major models used in the IPCC Third and Fourth Assessments, and also contributes to the Fifth Assessment. Its good simulation of current climate without using flux adjustments was a major advance at the time it was developed and it still ranks highly compared to other models in this respect (Reichler \& Kim, 2008). It also has the capability to capture the time-dependent fingerprint of historical climate change in response to natural and anthropogenic forcings (Stott et al. 2000) which has made it a particularly useful tool in studies concerning the detection and attribution of past climate changes. The scenarios chosen for future climate scenarios are $\mathrm{A} 2$ and $\mathrm{B} 2$ :

\section{A2 scenario:}

Regional heterogeneous development: High population growth. Economic development primarily regionally oriented. Economic growth and technological change are more fragmented and slower than in A1.

\section{B2 scenario:}

A world in which the emphasis is on local solutions to economic, social, and environmental sustainability. Moderate population growth, intermediate economic development, less rapid and more diverse technological change. Focussing on local and regional levels.

In order to finalize the downscaling method we retrieved predictor data from HadCM3 model output, for both A1 and B2 scenarios emission, at the nearest grid box $(35,352.5)$ of Rabat station.

\subsection{Standard Precipitation Index (SPI)}

The Standardized Precipitation Index (SPI) has been defined as a key indicator for monitoring drought by the World Meteorological Organization (WMO, 2012) and has been widely applied as an operational (Wilhite et al., 2000; McRoberts \& Nielsen-Gammon, 2011) and analysis tool. The SPI is a probabilistic indicator based purely on precipitation. The SPI was introduced by McKee et al. (1993) as measure of the precipitation deficit that is uniquely related to probability. It can be calculated for any accumulation timescale, usually from monthly precipitation observations, and is typically expressed as SPI-n, where $\mathrm{n}$ is the number of months of accumulation. The time series is analogous to a moving average in the sense that a new value is calculated each month and is auto-correlated to previous months depending on the accumulation timescale. The computation of SPI is based on an equi-probability transformation of the probability of observed precipitation to the standard normal variable with mean 0 and variance 1 . SPI is therefore expressed in units of the number of standard deviations from the mean, with negative (positive) values denoting drier (wetter) conditions than "expected" for the timescale and location. The standardization procedure to the standard normal variable means that the SPI is spatially and temporally invariant. This characteristic enables precipitation anomalies to be objectively compared between locations and times.

The SPI is defined as:

$$
S P I_{i}=\frac{X_{i}-\bar{X}}{S d}
$$

Where $S P I_{i}$ is the standardized precipitation index in the period $\mathrm{i} ; X i$ is the precipitation for the period $\mathrm{i} ; \overline{\boldsymbol{X}}$ is the mean precipitation in the period $i$ for the historical series; $S d$ is the standard deviation of the mean precipitation in the period $i$.

Table 2. SPI drought severity classes

\begin{tabular}{ll}
\hline SPI value & Class \\
\hline $\mathrm{SPI} \geq 2.00$ & Extremely wet \\
$1.50 \leq \mathrm{SPI} \leq 1.99$ & Very wet \\
$1.00 \leq \mathrm{SPI} \leq 1.49$ & Moderately wet \\
$-0.99 \leq \mathrm{SPI} \leq 0.99$ & Near normal \\
$-1.49 \leq \mathrm{SPI} \leq-1.00$ & Moderate dry \\
$-1.99 \leq \mathrm{SPI} \leq-1.50$ & Severe dry \\
$\mathrm{SPI} \leq-2.00$ & Extreme dry \\
\hline
\end{tabular}

The SPI index was calculated using observation data for the period of 1961-2001. For future periods 2014-2040, 
2041-2070 and 2071-2099 we used the monthly time series for precipitation and temperature derived from HadCM3 output ( $2.5^{\circ}$ latitude, $3.75^{\circ}$ longitude). To retrieve data for the Rabat station we extract the data of the nearest (latitude, longitude) grid box: $(35,352.5)$.

\section{Results and Discussion}

\subsection{Temperature and Precipitation Projections}

We have used NCEP daily data for the station of Rabat, from 1961 to 1985 and from 1986 to 2001 respectively to calibrate and validate the ASD model. The future monthly precipitation and temperature were simulated using the HadCM3 model with the A2 and B2 scenarios. The RMSE values for the monthly mean minimum and maximum temperature vary between $0.1-0.78$ for calibration and between $0.51-1.16$ for validation. This showed that ASD model reproduce reasonably the monthly minimum and maximum temperature.

Precipitations simulated are close to observations, but its have more accuracy under B2 scenario than A2. The precipitation projected was overestimated in winter and spring months (except January) and underestimated in autumn. The ASD model simulates temperature more accurately than precipitation. The HadCM3 outputs for monthly mean maximum and minimum temperature and precipitation were used for assessing climate changes impacts on drought severity and occurrence for the periods: 2014-2040, 2041-2070 and 2071-2099, under the A2 and B2 scenarios. (Figure 3)

The projected mean maximum and minimum temperature under the A2 and B2 scenarios will increase, especially for the 2071-2099 period. Using B2 scenario the difference between observed and projected data was lower than under A2 scenario in the calibration and validation. Increasing maximum and minimum temperature under $\mathrm{A} 2$ scenario is higher than under the $\mathrm{B} 2$ scenario. The range of the maximum temperature under $\mathrm{A} 2$ varies from $2.5^{\circ} \mathrm{C}$ to $4.6{ }^{\circ} \mathrm{C}$. For winter is $2.8{ }^{\circ} \mathrm{C}$ to $4.6^{\circ} \mathrm{C}$, for spring is $2.5^{\circ} \mathrm{C}$ to $4.2{ }^{\circ} \mathrm{C}$, for summer is $3{ }^{\circ} \mathrm{C}$ to $3.9{ }^{\circ} \mathrm{C}$ and for autumn is $3{ }^{\circ} \mathrm{C}$ to $4.5^{\circ} \mathrm{C}$. Under B2 it varies from $1.3^{\circ} \mathrm{C}$ to $2.8{ }^{\circ} \mathrm{C}$, and for the four seasons it range from 1.5 to $2.8^{\circ} \mathrm{C}, 1.3$ to $2.3^{\circ} \mathrm{C}, 1.9$ to $2.6^{\circ} \mathrm{C}$ and 2.3 to $2.8^{\circ} \mathrm{C}$ in winter, spring, summer and autumn respectively.

The range of the mean minimum temperature under $\mathrm{A} 2$ varies from $1.7^{\circ} \mathrm{C}$ to $3.0^{\circ} \mathrm{C}$ and 0.9 to $2.1{ }^{\circ} \mathrm{C}$ under $\mathrm{B} 2$. The annual mean maximum temperature under A2 scenario increased by $2.24 \%, 7.43 \%$ and $16.31 \%$ for 2014-2040, 2041-2070 and 2071-2099 periods respectively, and for the B2 scenario increased by $3.07 \%$, 6.97\% and $10.0 \%$ for 2014-2040, 2041-2070 and 2071-2099 periods respectively. The highest rate for mean minimum temperature was $3.0^{\circ} \mathrm{C}$, under the $\mathrm{A} 2$ scenario and $2.1^{\circ} \mathrm{C}$ under B2 both of them occurred in summer.

Projected mean precipitations increased with comparison to the past period. Monthly mean precipitations increased in all months except for January and September (Figure 3). The annual precipitations under A2 scenario increased by $4.72 \%, 4.75 \%$ and $4.50 \%$ for the periods 2014-2040, 2041-2070 and 2071-2099 respectively, and for the B2 scenario increased by $4.19 \%, 5.0 \%$ and $4.58 \%$ for the $2014-2040,2041-2070$ and 2071-2099 periods respectively. Annual mean precipitations increase much higher under B2 scenario than under A2 scenario for the 2041-2070 and 2071-2099 periods and lower than under A2 scenario for the 2014-2040) period. The month of April 2071-2099 have the highest increase in the mean precipitation under the two scenarios. 

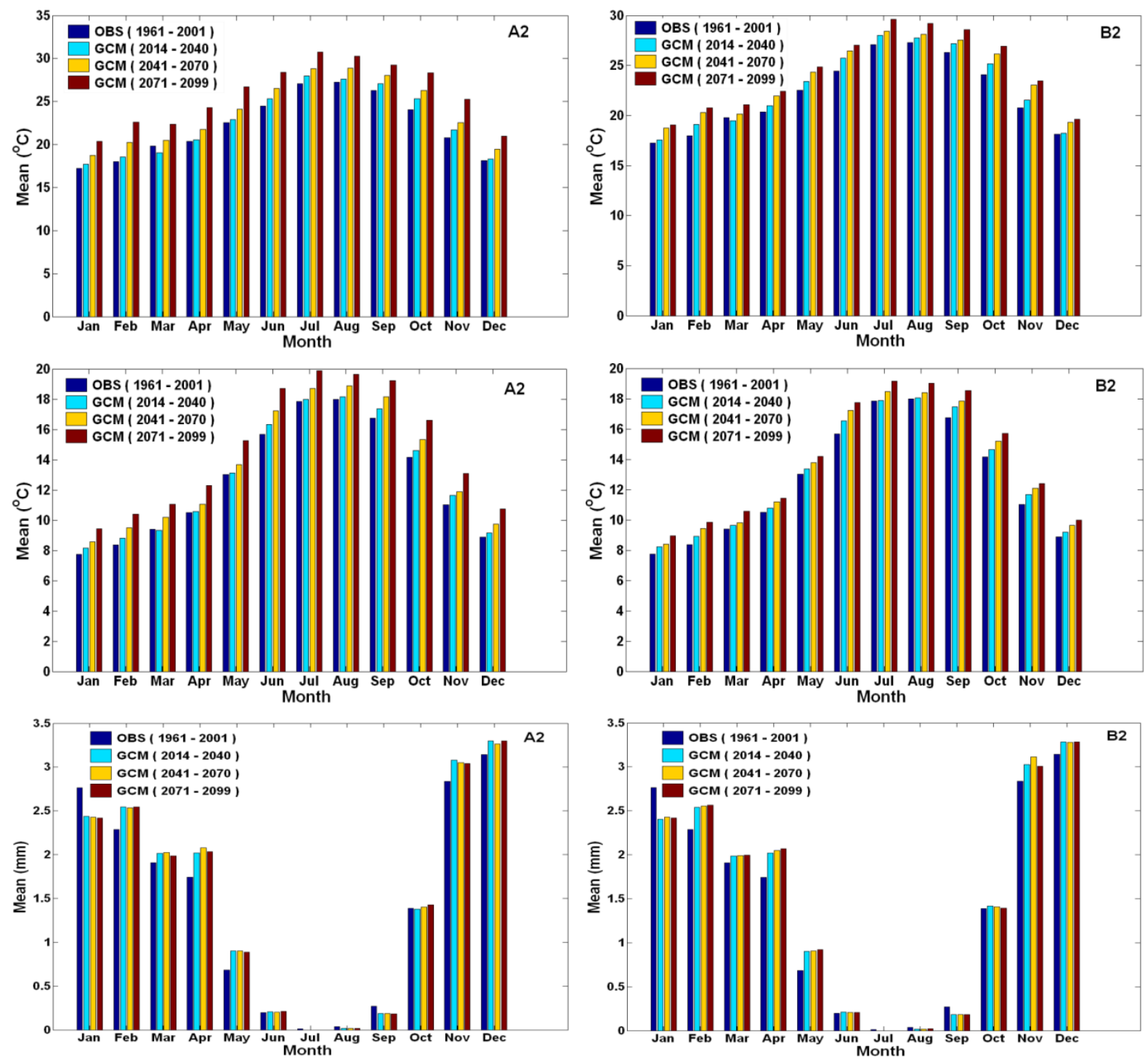

Figure 3. Mean maximum (top), minimum (middle) and precipitation (bottom) for past and future periods under A2 (left) and B2 (right) scenarios for Rabat Station

\subsection{SPI Drought Index}

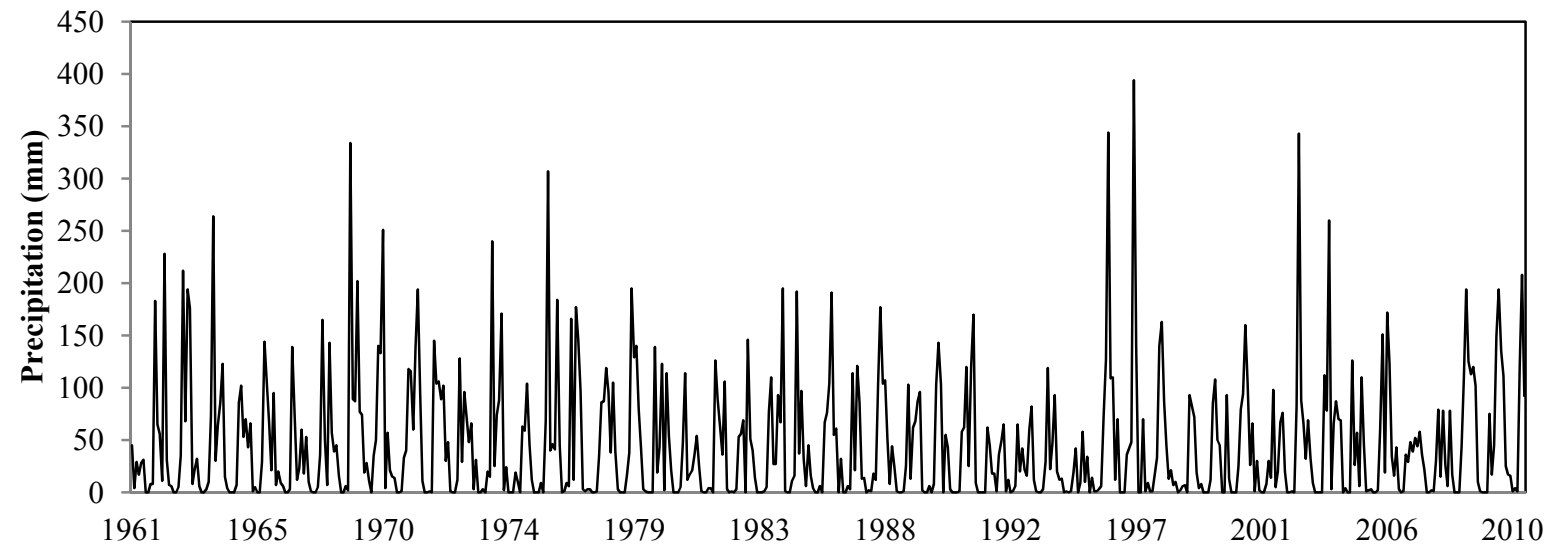

Figure 4. Time series of the monthly mean precipitation in Rabat 

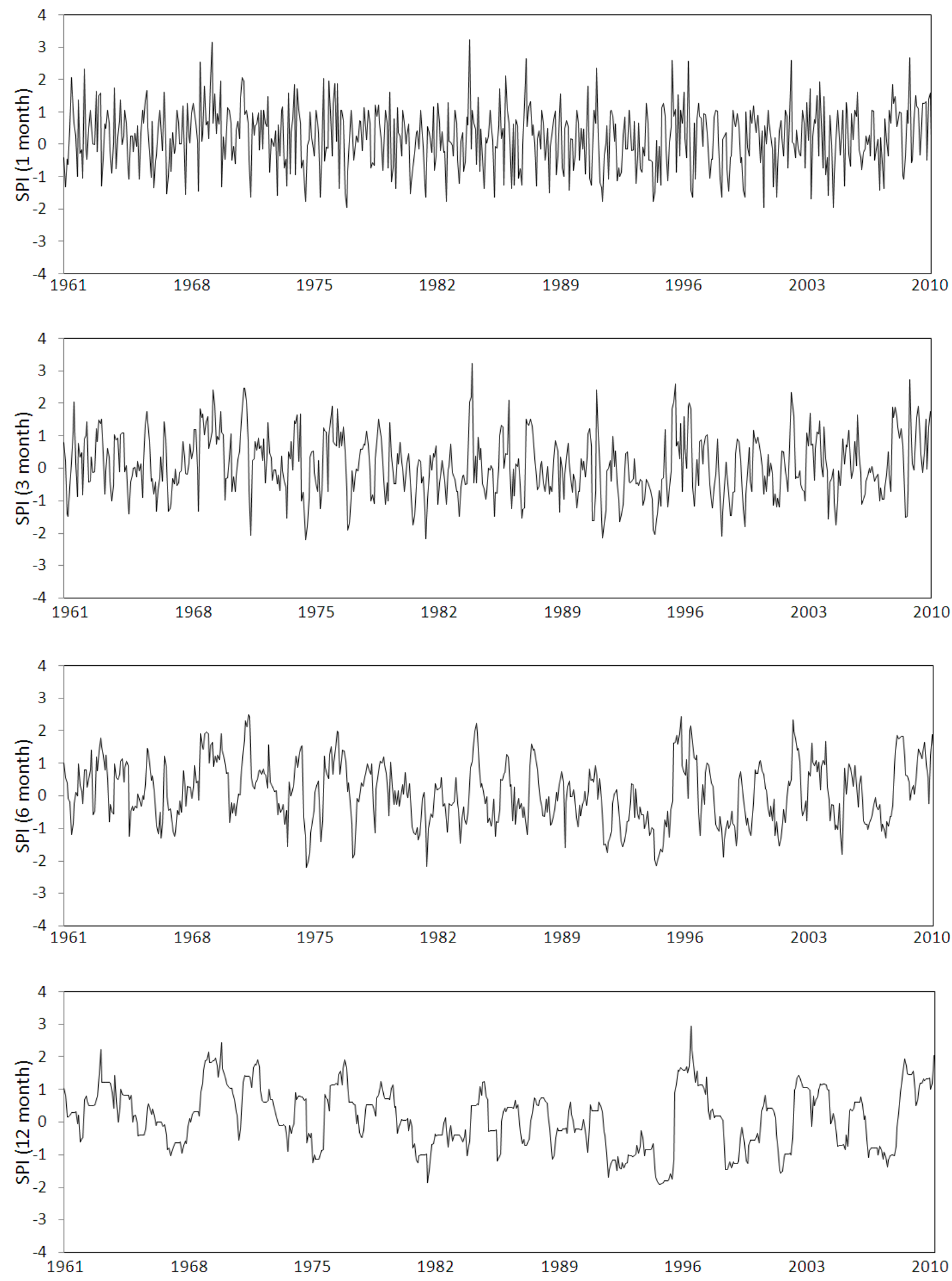

Figure 5. SPI time series for Rabat at 1, 3, 6, 12 months time step 
Table 3. SPI statistics for the study period

\begin{tabular}{lcccc}
\hline & 1 month & 3 month & 6 month & 12 month \\
\hline Number of cases with SPI $<0$ & 233 & 305 & 291 & 266 \\
The longest duration of drought & 5 & 20 & 25 & 49 \\
Period of longest duration & $1974-1975$ & $1993-1995$ & $1993-1995$ & $1991-1995$ \\
& $1994-1995$ & & & \\
& $2006-2007$ & & & \\
Number of cases with SPI $>0$ & 362 & 290 & 308 & 331 \\
The longest duration of wet & 15 & 17 & 27 & 36 \\
period of the longest duration & $1969-1970$ & $1968-1970$ & $1971-1973$ & $1962-1965$ \\
\hline
\end{tabular}

\subsection{Assessing Drought Trends}

\subsubsection{Past Period}

The monthly rainfall in Rabat for the period 1961-2010 is represented in the figure 4. It shows the variability of precipitation with an alternation of shorter or longer dry and wet episodes. Figure 5 shows the SPI time series for different month's steps. The minimum value of SPI is observed in December of 1974. The analysis of the 6 and 12 months SPI series reveals a frequent drought during 1966-1967, 1980-1982, 1993-1995 and 2007-2008. The year 1994 of the dry period of 1993-1995 have the smallest annual precipitations of the study period. The number of dry and wet months and duration of drought and wet periods for the study period is shown in Table 3 .

\subsubsection{Future Trends}

We use the projected SPI index under A2 and B2 scenario (Figure 6) to estimate future drought severity for Rabat region. Visual inspection of SPI time series at 1,3,6, and 12 months showed an overall decrease of annual and seasonal drought severity over the years. The annual and seasonal drought severity and duration for the periods 2025-2045 and 2055-2070 will increase under A2 and decrease under B2 scenario. The scenario A2 predict higher severe drought than B2 scenario.

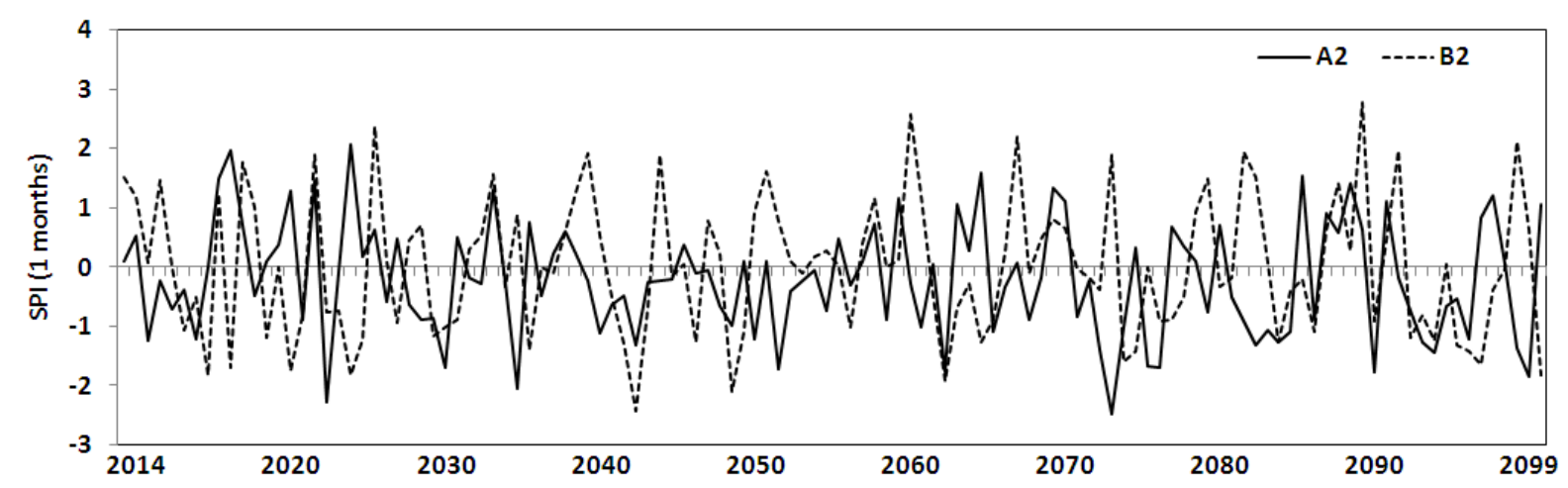



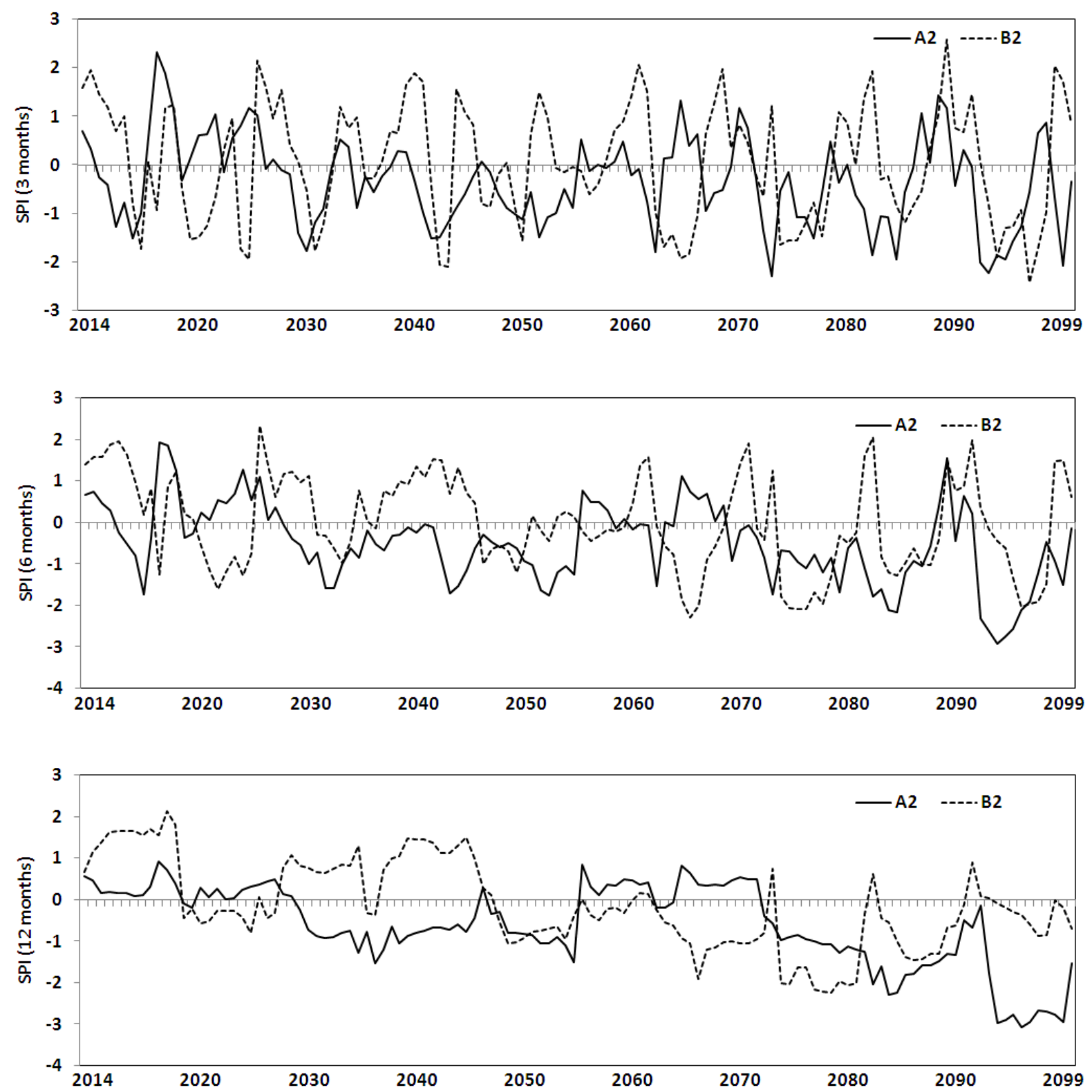

Figure 6. Future projections (for A2 and B2 scenarios) of SPI time series for Rabat at 1, 3, 6, 12 months time step

\section{Conclusion}

A study of historical and future precipitation and temperature for the region of the Bouregreg basin is presented in this paper; we used the HadCM3 model outputs to estimate the future trends of precipitations and temperature for the periods: 2014-2040, 2041-2070 and 2071-2099. This study showed an increase in mean temperature and precipitation for the region of Bouregreg basin in the northwest of Morocco as a result of increasing greenhouse gases in the atmosphere. The emission scenarios A2 and B2 from IPCC have been used. The results of this study showed an increasing trend for the projected annual mean precipitations and temperature under both emission scenarios A2 and B2 for the three study periods. The annual mean minimum temperature will increase by $2.1{ }^{\circ} \mathrm{C}$ and $1.4{ }^{\circ} \mathrm{C}$ for the period $2071-2099$ under $\mathrm{A} 2$ and B2 scenarios respectively, while the annual mean maximum temperature will increase by $3.6^{\circ} \mathrm{C}$ and $2.2{ }^{\circ} \mathrm{C}$ under $\mathrm{A} 2$ and B2 for the same period. The analysis of drought occurrence and severity showed an increasing of annual and seasonal drought severity and duration for the periods 2025-2045 and 2055-2070 under A2 scenario and decreasing under B2 scenario. The results of this study showed that drought duration and severity in Morocco northwest region will be affected by climate changes, 
therefore mitigation tools and water management projects should be deployed in order to reduce its impacts.

\section{References}

Afifi, A. A., \& Clark, V. (1996). Computer-aided multivariate analysis (3rd ed.). London: Chapman \& Hall.

Andrew, S. (2012). Forecasting Drought in Europe with the Standardized Precipitation Index, Scientific and Technical Research series. http://dx.doi.org/10.2788/16522

Bonferroni, C. E. (1936). "Teoria statistica delle classi e calcolo delle probabilità." Pubblicazioni del R Istituto Superiore di Scienze Economiche e Commerciali di Firenze, 8, 3-62.

Funnell, D. C., \& Parish, R. (1999). Complexity, cultural theory and strategies for intervention in the High Atlas of Morocco. Geografiska Annaler: Series B. Human Geography, 81, 131-144. http://dx.doi.org/10.1111/j.0435-3684.1999.00900.x

Giorgi, F. et al. (2001). Regional climate information-evaluation and projections. In J. T. Houghton et al. (Eds.), Climate Change 2001: The Scientific Basis. Contribution of Working Group I to the Third Assessment Report of the Intergovernmental Panel on Climate Change (pp. 583-638). Cambridge University Press, Cambridge, United Kingdom and New York, NY, USA.

Hessami, M., Gachon, P., Ouarda, T., \& Hilaire-St, A. (2008). An automated regression-based statistical downscaling tool. Environ. Modell. Softw, 23, 813-834. http://dx.doi.org/10.1016/j.envsoft.2007.10.004

Hoerl, A. E., \& Kennard, R. W. (1970). Ridge regression: Application to nonorthogonal problems. Technometrics, 12(1), 69-82.

IPCC. (2000). IPCC special report emissions scenarios. Summary for Policymakers. Based on a draft prepared by: Nakic'enovic, N., Davidson, O., Davis, G., Gr”ubler, A., Kram, T., La Rovere, E.L., Metz, B., Morita, T., Pepper, W., Pitcher, H., Sankovski, A., Shukla, P., Swart, R., Watson, R., Dadi, Z., ISBN, 92-9169-113-5.

Lawrimore, J. H., Menne, M. J., Gleason, B. E., Williams, C. N., Wuertz, D. B., Vose, R. S., \& Rennie, J. (2011). An overview of the Global Historical Climatology Network monthly mean temperature data set, version 3, J. Geophys. Res., 116, D19121. http://dx.doi.org/10.1029/2011JD016187

Juneng, L., Tangang, F. T., Kang, H., Lee, W. J., \& Seng, Y. K. (2010). Statistical downscaling forecasts for winter monsoon precipitation in Malaysia using multimodel output variables. J. Clim., 23, 17-27. http://dx.doi.org/10.1175/2009JCLI2873.1

Born, K., \& Fink, A. H. et al. (2008). Dry and Wet Periods in the Northwestern Maghreb for Present Day and $\begin{array}{llll}\text { Future Climate } \quad \text { Conditions. } & \text { Zeitschrift, }\end{array}$ http://dx.doi.org/10.1127/0941-2948/2008/0313

Kalnay, E., Kanamitsu, M., \& Kistler, R. et al. (1996). The NCEP/NCAR 40-year reanalysis project. Bull. Am. Meteorol. Soc., 77, 437-471. http://dx.doi.org/10.1175/1520-0477(1996)077<0437:TNYRP>2.0.CO;2

Knippertz, P., Christoph, M., \& Speth, P. (2003). Long-term precipitation variability in Morocco and the link to the large-scale circulation in recent and future climates. Meteorology and Atmospheric Physics, 83, 67-88. http://dx.doi.org/10.1007/s00703-002-561-y

Le-Hou'erou, H. N., \& Hoste, C. H. (1977). Rangeland production and annual rainfall relations in the Mediterranean basin and in the African Sahelo-Sudan zone. Journal of Range Management, 30, 181-189.

Loukas, A., Vasiliades, L., \& Tzabiras, J. (2008). Climate change effects on drought severity. Adv. Geosci., 17, 23-29. http://dx.doi.org/10.5194/adgeo-17-23-2008

McRoberts, D. B., \& Nielsen-Gammon, J. W. (2011). A modified Standardized Precipitation Index for drought monitoring. Data-driven Approaches to Drought Symposium, Purdue University, West Lafayette, IN.

Sayari, N. et al. (2013). Using drought indices to assess climate change impacts on drought conditions in the northeast of Iran (case study: Kashafrood basin), METEOROLOGICAL APPLICATIONS Meteorol. Appl., 20, 115-127. http://dx.doi.org/10.1002/met.1347

Nicholson, S. E., \& Kim, J. (1997). The relationship of the El Nĩno Southern Oscillation to African rainfall. Int. J. Climatol., $\quad 17, \quad$ 117-135. $\quad$ http://dx.doi.org/doi: 10.1002/(SICI)1097-0088(199702) 17:2<117::AID-JOC84>3.0.CO;2-O

Knippertz, P. et al. (2003). Long-term precipitation variability in Morocco and the link to the large-scale circulation in recent and future climates. Meteorol Atmos Phys, 83, 67-88. http://dx.doi.org/10.1007/s00703-002-0561-y 
Reichler, T., \& Kim, J. (2008). How Well Do Coupled Models Simulate Today's Climate? Bull. Amer. Meteor. Soc., 89, 303-311. http://dx.doi.org/10.1175/BAMS-89-3-303

Smith, J. B., \& Hulme, M. (1998). Climate change scenarios Chapter 3 in, Handbook on methods of climate change impacts assessment and adaptation strategies: Version 2.0 (eds.) Feenstra, J., Burton, I., Smith, J. B., and Tol, R. S. J., October, UNEP/IES, Amsterdam.

Stott, et al. (2000). External Control of 20th Century Temperature by Natural and Anthropogenic Forcings. Science 15 December 2000, 290(5499), 2133-2137. http://dx.doi.org/10.1126/science.290.5499.2133

Carter1, T. R. (2007). General guidelines on the use of scenario data for climate impact and adaptation assessment. Version 2, June 2007, TGICA.

Wilby, R. L., Dawson, C. W., \& Barrow, E. M. (2002). SDSM - a decision support tool for the assessment of regional climate change impacts. Environmental Modeling \& Software, 17, 147-159. http://dx.doi.org/10.1016/S1364-8152(01)00060-3

Wilby, R. L., Hay, L. E., \& Leavesley, G. H. (1999). A comparison of downscaled and raw GCM output: implications for climate change scenarios in the San Juan River basin. Colorado, Journal of Hydrology, 225, 67-91. http://dx.doi.org/10.1016/S0022-1694(99)00136-5

Wilhite, D. A., Hayes, M. J., \& Svodoba, M. D. (2000). Drought monitoring and assessment: Status and Trends in the U.S. Drought and drought mitigation in Europe, Voght JV, Somma F (eds). Kluwers: Dordrecht. http://dx.doi.org/10.1007/978-94-015-9472-1_11

World Meteorological Organization. (2012). Standardized Precipitation Index User Guide (M. Svoboda, M. Hayes and D. Wood). (WMO-No. 1090), Geneva.

Wu, H., Hayes, M. J., Wilhite, D. A., \& Svoboda, M. D. (2005). The effect of the length of record on the standardized precipitation index calculation. Int. J. Climatol., 25, 505-520. http://dx.doi.org/10.1002/joc.1142

\section{Copyrights}

Copyright for this article is retained by the author(s), with first publication rights granted to the journal.

This is an open-access article distributed under the terms and conditions of the Creative Commons Attribution license (http://creativecommons.org/licenses/by/3.0/). 